\title{
The Impact of Public Debt on Economic Growth of ASEAN + 3 Countries
}

\author{
Submitted 11/08/20, $1^{\text {st }}$ revision 29/08/20, $2^{\text {nd }}$ revision 25/09/20, accepted 10/10/20
}

\section{Pham Thi Ha An ${ }^{1}$, Mai Binh Duong ${ }^{2}$, Nguyen Trong Toan ${ }^{3}$ \\ Abstract:}

Purpose: The study applied the threshold regression method proposed by Hansen (1999) with panel data (Panel Threshold Regression-PTR) to determine the existence of threshold effects and threshold values of public debt affecting the economic growth of ASEAN+3 countries.

Design/Methodology/Approach: The model of the impact of public debt on economic growth was developed by the authors based on the study by Égert (2015) and conducted by the authors using three samples, including all countries, high-income countries, and middleincome countries for the period 2004-2015.

Findings: The study results showed that, with the sample of all ASEAN +3 countries, two public debt thresholds on GDP were $26.96 \%$ and $72.53 \%$. With a sample of high-income countries, one public debt threshold on GDP was $65.80 \%$. For the sample of middle-income countries, two public debt thresholds on GDP were $26.96 \%$ and $72.53 \%$. More specifically, for middle-income countries, at public debt levels below $26.96 \%$ of GDP and from $72.53 \%$ of GDP, public debt will have a negative and statistically significant impact on economic growth. At public debt levels ranging from $26.96 \%$ of GDP to $72.53 \%$ of GDP, public debt does not affect economic growth, but these levels promote public expenditure that positively affects economic growth.

Practical implications: Based on the research results, policymakers can use these thresholds in managing national public debt.

Originality/Value: Although this study organically builds upon recent studies about public debt and economic growth, it provides a new method to determine the effect of public debt on economic growth using the threshold regression method proposed by Hansen (1999) with panel data (Panel Threshold Regression-PTR).

Keywords: Public Debt Threshold, PTR Method, Bootstrap.

JEL Codes: H6, H68, E62.

Paper Type: Research article.

${ }^{1}$ Faculty of Finance and Banking, Van Lang University, Ho Chi Minh city, Vietnam.

E-mail: phamthihaan@vanlanguni.edu.vn

${ }^{2}$ Faculty of Accounting and Auditing, Van Lang University, Ho Chi Minh city, Vietnam.

E-mail: maibinhduong@vanlanguni.edu.vn

${ }^{3}$ Faculty of Finance and Banking, Van Lang University, Ho Chi Minh city, Vietnam.

E-mail: trongtoanvlu@gmail.com 


\section{Introduction}

Public debt plays an important role in countries' investment activities, thereby impacting economic growth, employment, and inflation. Public debt issues were studied early, but theoretically, the impact of this relationship is still conflicting. There are currently three basic concepts relating to the impact of public debt on economic growth, including:

First, public debt promotes economic growth: Many studies ignore the public debt thresholds argument and state that public debt only impacts economic growth promotion. The traditional view, represented by Keynes (1936), was of significance, arguing that public debt will stimulate growth by increasing government resources if maintained at a reasonable level. Capital is the most important factor, especially for developing countries that want to build up and synchronize infrastructure quickly. With a reasonable policy of mobilizing public debt, investment in infrastructure will gradually resolve the demand for capital, thereby increasing the economy's production capacity (George, 2014; PrasadBal and NarayanRath, 2014; ChecheritaWestphal and Rother, 2012; Aschauer, 1989).

Second, public debt constrains economic growth: In contrast to the traditional view of public debt, those who follow the perspectives of Ricardo (1951), Barro (1989) claims that tax cuts offset by government debt do not boost short-term investment as it does not raise individuals' daily incomes but instead transfers taxes from present to future. Tax cuts and debt financing will not have a real impact on the economy. Accepting the revenue deficit during the recession and revenue increase in the prosperous period and borrowing loans are also ways of "tax circulation" to minimize the negative impact of taxes on the business cycle. The tax cuts offset by government debt will not affect consumption, as in the traditional view of debt, even in the short term. On the contrary, it will increase private savings because people are preparing for high taxes that will come in the future to pay for interest and principal on existing debts (Eisner, 1992; Hameed, Ashraf, and Chaudhary, 2008; Kumar and Woo, 1988; Baum, Checherita-Westphal, and Rother, 2013; Amano and Wirjanto, 1997; Gwartney, Lawson, and Holcombe, 1998).

Indeed, these two viewpoints are also parallel. Public debt has both a stimulating and restricting impact on economic development. According to Elmendorf and Mankiw (1999), if public debt rises for budget deficit adjustment purposes, this would have a positive effect on short-term economic development and catalyze aggregate demand. In the long run, though, debt can hurt growth because of the crowding-out effect on capital. Teles and Mussolini (2014) recently developed theories about the relationship between public debt and economic growth by proposing a generationsrelated model and endogenous growth. In particular, thanks to efficient public spending, public debt can positively impact and have a negative impact due to reduced investment and increased tax requirements. Countries with higher public debt rates will experience more of the phenomenon of "crowding out private 
investment." However, this study has not yet discussed the determination of the high or low level of public debt and what rate is best.

So, the above studies do not present a common conclusion about the relationship between public debt and economic growth, which may be due to different research methods, settings, and periods. Moreover, public debt originates from a budget deficit and the purpose of seeking capital for economic growth. However, in most countries, budget deficit basically depends on the annual revenue and expenditure plan of state management agencies, or in other words, a part of public debt and budget deficit stems from many subjective factors that can be regulated, with the ultimate goal of economic growth. Having said that, researching the relationship between public debt and economic growth under the influence of macro variables can still provide useful policy recommendations in debt management and national budget regulation from which to formulate effective fiscal policies. Therefore, it is rational to assume that the relationship between public debt and economic growth is nonlinear and U-shaped inverted, i.e., with low and moderate rates of public debt, it has a positive effect on economic growth, but when public debt increases and exceeds a threshold point, public debt has the effect of limiting economic growth.

\section{Methodology and Database}

The model of this study is based on the research by Égert (2015) of the nonlinear relationship between total public debt and economic growth of a mixture of 58 developed and developing countries; individual samples include 20 developed countries (high income) and 41 developing countries (low and middle income) from 1946 to 2009. Specifically, the model considers the impact of public debt on economic growth in the ASEAN+3 countries (Viet Nam, Lao, Cambodia, Thailand, Malaysia, Myanmar, Indonesia, Philippines, Brunei, Singapore, + Japan, S. Korea, China) based on the Cobb-Douglas production function, including the proposed main variables.

First, the authors review the model of the impact of public debt on economic growth in ASEAN+3 countries with one threshold of public debt, as follows:

$$
\operatorname{lngdp_{t}}=\left\{\begin{array}{l}
\alpha_{1}+\sum_{j=1}^{n} \beta_{j} \cdot X_{j, t}+\emptyset_{1} \cdot \text { debt }_{t}+\varepsilon_{t} \text { if } \text { debt }<\gamma \\
\alpha_{1}+\sum_{j=1}^{n} \beta_{j} \cdot X_{j, t}+\emptyset_{2} \cdot \text { debt }_{t}+\varepsilon_{t} \text { if debt } \geq \gamma
\end{array}\right.
$$

Next, the authors review the model of the impact of public debt on economic growth in ASEAN+3 countries with two thresholds of public debt, as follows: 


$$
\operatorname{lngdp_{t}}=\left\{\begin{array}{rrr}
\alpha_{1}+\sum_{j=1}^{n} \beta_{j} \cdot X_{j, t}+\emptyset_{1} \cdot \text { debt }_{t}+\varepsilon_{t} & \text { if } \quad \text { debt }<\gamma_{1} \\
\alpha_{1}+\sum_{j=1}^{n} \beta_{j} \cdot X_{j, t}+\emptyset_{2} \cdot \text { debt }_{t}+\varepsilon_{t} & \text { if } & \gamma_{1} \leq \text { debt }<\gamma_{2} \\
\alpha_{1}+\sum_{j=1}^{n} \beta_{j} \cdot X_{j, t}+\emptyset_{3} \cdot \text { debt }_{t}+\varepsilon_{t} & \text { if } & \text { debt } \geq \gamma_{2}
\end{array}\right.
$$

Data on the variables in the model is shown in Table 1 below:

Table 1. Description of study variables

\begin{tabular}{|c|c|c|c|c|}
\hline Variables & Symbol & Measurement & $\begin{array}{l}\text { Expected } \\
\text { impact }\end{array}$ & Data source \\
\hline \multicolumn{5}{|c|}{ Dependable variables } \\
\hline $\begin{array}{l}\text { Economic } \\
\text { growth }\end{array}$ & $\ln g d p_{i t}$ & $\begin{array}{l}\text { Natural logarithm of } \\
\text { GDP per capita of } \\
\text { country i in year } \mathrm{t}\end{array}$ & & $\begin{array}{l}\text { World Economic } \\
\text { Outlook, World } \\
\text { Development } \\
\text { Indicators }\end{array}$ \\
\hline \multicolumn{5}{|c|}{ Independent variables } \\
\hline $\begin{array}{l}\text { Private } \\
\text { investment } \\
\text { capital }\end{array}$ & $i n v_{i t}$ & $\begin{array}{l}\text { Private investment } \\
\text { capital over GDP of } \\
\text { country } \mathrm{i} \text { in year } \mathrm{t}\end{array}$ & + & $\begin{array}{l}\text { World Economic } \\
\text { Outlook, World } \\
\text { Development } \\
\text { Indicators }\end{array}$ \\
\hline $\begin{array}{l}\text { Human } \\
\text { capital }\end{array}$ & $l_{i t}$ & $\begin{array}{l}\text { Labor force } \\
\text { participation rate of } \\
\text { country } \mathrm{i} \text { in year } \mathrm{t}\end{array}$ & + & $\begin{array}{l}\text { United Nations } \\
\text { Development } \\
\text { Program's } \\
\end{array}$ \\
\hline $\begin{array}{l}\text { Public } \\
\text { capital }\end{array}$ & $g_{i t}$ & $\begin{array}{l}\text { Public expenditure over } \\
\text { GDP of country } i \text { in } \\
\text { year } t\end{array}$ & $+/-$ & $\begin{array}{l}\text { World Economic } \\
\text { Outlook, World } \\
\text { Development } \\
\text { Indicators }\end{array}$ \\
\hline Public debt & $d e b t_{i t}$ & $\begin{array}{l}\text { Public debt over GDP } \\
\text { of country } \mathrm{i} \text { in year } \mathrm{t}\end{array}$ & - & $\begin{array}{l}\text { World Economic } \\
\text { Outlook, World } \\
\text { Development } \\
\text { Indicators }\end{array}$ \\
\hline
\end{tabular}

Source: Suggested by the authors.

\subsection{Database}

As a rule of thumb, the sample size must be at least 5 times the number of variables in the model (Hair, Anderson, Tatham, and Black, 1998). The experimental research model consists of a maximum of 5 variables, so the minimum sample size is 25 observations. With panel data covering 13 countries collected from 2004 to 2015 , the sample consists of $13 \times 12=156$ observations and meets the requirements of suitability. 
In terms of timing, the authors conducted the study in 13 countries from 2004 to 2015, collected from the World Economic Outlook (WEO) data set of the International Monetary Fund (IMF) and the World Development Indicators (WDI) of the World Bank for 13 ASEAN+3 countries. This period of time was selected by the authors for a variety of reasons. Firstly, this period ensures that 13 countries have sufficient data to conduct research. Secondly, this research period includes the pre-crisis period 2004-2007, the crisis period 2008-2009, and the post-crisis period 2010-2015. Therefore, the authors can consider the overall impact of public debt on economic growth in ASEAN+3 countries.

\section{Empirical Results and Discussion}

\subsection{Testing the Existence of Threshold Effects}

To test the existence of threshold effects, the bootstrap method was performed 300 times to give a p-value of a reasonable rate test of 0.02 , smaller than the significance level of $5 \%$. Therefore, there exists a threshold effect in the model with the sample being all ASEAN+3 countries.

Table 2. Testing the existence of threshold effects for all countries Threshold estimator (level = 95):

\begin{tabular}{|c|c|c|c|c|c|c|c|c|}
\hline \multicolumn{2}{|c|}{ model } & \multicolumn{3}{|c|}{ Threshold } & \multicolumn{2}{|c|}{ Lower } & \multicolumn{2}{|r|}{ Upper } \\
\hline \multicolumn{2}{|c|}{ Th-1 } & \multicolumn{3}{|c|}{0.2696} & \multicolumn{2}{|c|}{0.2614} & \multicolumn{2}{|c|}{0.2700} \\
\hline \multicolumn{9}{|c|}{ Threshold effect test (bootstrap $=300)$ : } \\
\hline Threshold & & RSS & MSE & Fstat & Prob & Crit10 & Crit5 & Crit1 \\
\hline Single & & 1.6969 & 0.0118 & 42.46 & 0.0200 & 24.9166 & 29.1970 & 49.7877 \\
\hline
\end{tabular}

Source: Results calculated from Stata 16 software.

The bootstrap method was performed 300 times to test the presence of threshold effects to give a p-value of a fair rate test of 0.00 , lower than the significance level of 5 percent. Thus, a threshold effect occurs in the model, with the sample being high-income countries like Brunei, Japan, and Singapore (Table 3):

Similar to the above, the bootstrap method was performed 300 times to give a pvalue of a 0.01 reasonable rate test-lower than 5 percent meaning level. Therefore a threshold effect exists in the model, the sample being middle-income countries (Table 4). 
Table 3. Testing the existence of threshold effects for high-income countries Threshold effect test (bootstrap $=300$ ):

\begin{tabular}{r|rrrrrrr}
\hline Threshold & RSS & MSE & Fstat & Prob & Crit10 & Crit5 & Crit1 \\
\hline Single & 0.0559 & 0.0023 & 11.96 & 0.0000 & 5.6442 & 7.1107 & 8.0977 \\
\hline
\end{tabular}

\begin{tabular}{|c|c|c|c|}
\hline model & Threshold & Lower & Upper \\
\hline Th-1 & 0.0281 & 0.0225 & 0.9149 \\
\hline
\end{tabular}

Source: Results calculated from Stata 16 software

Table 4. Testing the existence of threshold effects for middle-income countries Threshold estimator (level = 95):

\begin{tabular}{|c|c|c|c|c|c|c|c|}
\hline \multicolumn{2}{|c|}{ model } & \multicolumn{2}{|l|}{ Threshold } & \multicolumn{2}{|c|}{ Lower } & \multicolumn{2}{|r|}{ Upper } \\
\hline Th-1 & \multicolumn{3}{|c|}{0.2937} & \multicolumn{2}{|c|}{0.2921} & \multicolumn{2}{|c|}{0.2973} \\
\hline \multicolumn{8}{|c|}{ Threshold effect test (bootstrap $=300$ ): } \\
\hline Threshold & RSS & MSE & Fstat & Prob & Crit10 & Crit5 & Crit1 \\
\hline Single & 1.2024 & 0.0111 & 37.71 & 0.0100 & 22.7559 & 26.0080 & 33.2494 \\
\hline
\end{tabular}

Source: Results calculated from Stata 16 software

\subsection{Testing the Number of Thresholds in the Model}

The model of the effect of public debt on economic growth in ASEAN+3 countries is checked with the number of thresholds for public debt, respectively 1, 2, and 3 . For each 1, 2, and 3-threshold test, the authors used the bootstrap method with 300 samples. Specifically, the test with 1 level of public debt is also the test with a threshold effect that was carried out above.

Tests with 2 and 3 public debt thresholds are conducted after the threshold effect existing test. Since these tests are carried out later and using the test results at one public debt threshold in Tables 5, 6, and 7, the bootstrap results show 0 for the one threshold test, 300 for the two thresholds test, and 300 for the three thresholds test.

The following Table 5 presents the test results of the number of thresholds with the sample being in all countries: 
Table 5. Test of the number of thresholds with the sample being all countries Threshold estimator (level = 95):

\begin{tabular}{r|rcr}
\hline model & Threshold & Lower & Upper \\
\hline Th-1 & 0.2696 & 0.2614 & 0.2700 \\
Th-21 & 0.2696 & 0.2614 & 0.2700 \\
Th-22 & 0.7253 & 0.6901 & 0.7403 \\
Th-3 & 0.2937 & 0.0098 & 0.2973 \\
\hline
\end{tabular}

Threshold effect test (bootstrap $=0300300$ ):

\begin{tabular}{c|rrrrrrr}
\hline Threshold & RSS & MSE & Fstat & Prob & Crit10 & Crit5 & Crit1 \\
\hline Single & 1.6969 & 0.0118 & 42.46 & 0.0200 & 24.9166 & 29.1970 & 49.7877 \\
Double & 1.4311 & 0.0099 & 26.75 & 0.0933 & 25.9863 & 30.2760 & 46.0122 \\
Triple & 1.2734 & 0.0088 & 17.84 & 0.7333 & 43.6985 & 47.5760 & 70.1924 \\
\hline
\end{tabular}

Source: Results calculated from Stata 16 software.

The p-value of the reasonable rate test corresponding to the model with two public debt thresholds is 0.0933 , smaller than the significance level of $10 \%$. Besides, the pvalue corresponding to the model with three public debt thresholds is 0.7333 , which is larger than the significance level of $10 \%$. Thus, the model of the impact of public debt on the economic growth of all ASEAN +3 countries has two values of public debt threshold (Table 6):

Table 6. Test of the number of thresholds with the sample being high-income countries

\begin{tabular}{c|ccr} 
Threshold estimator (1evel $=95):$ \\
\hline mode1 & Threshold & Lower & Upper \\
Th-1 & 0.0281 & 0.0225 & 0.9149 \\
Th-21 & 0.0281 & 0.0221 & 0.9510 \\
Th-22 & 1.0416 & 1.0390 & 1.0468 \\
Th-3 & 1.8644 & - & - \\
\hline
\end{tabular}

Threshold effect test (bootstrap $=0300300$ ):

\begin{tabular}{c|rrrrrrr}
\hline Threshold & RSS & MSE & Fstat & Prob & Crit10 & Crit5 & Crit1 \\
\hline Single & 0.0559 & 0.0023 & 11.96 & 0.0000 & 5.6442 & 7.1107 & 8.0977 \\
Double & 0.0496 & 0.0021 & 3.05 & 0.4467 & 6.1086 & 7.1661 & 10.9915 \\
Triple & 0.0459 & 0.0019 & 1.89 & 0.5400 & 5.9730 & 8.3172 & 10.8700 \\
\hline
\end{tabular}

Source: Results calculated from Stata 16 software

The p-value of a reasonable rate test corresponding to a model with two public debt thresholds is 0.4467 , which is larger than the significance level of $10 \%$. Thus, the 
model of the impact of public debt on the economic growth of high-income countries in the ASEAN+3 region only has one existing value of public debt threshold (Table 7):

Table 7. Test of the number of thresholds with the sample being middle-income countries

Threshold estimator (level = 95):

\begin{tabular}{r|rrr}
\hline model & Threshold & Lower & Upper \\
\hline Th-1 & 0.2937 & 0.2921 & 0.2973 \\
Th-21 & 0.2696 & 0.2614 & 0.2700 \\
Th-22 & 0.7253 & 0.6901 & 0.7403 \\
Th-3 & 0.2937 & 0.2921 & 0.2973 \\
\hline
\end{tabular}

Threshold effect test (bootstrap $=0300300$ ):

\begin{tabular}{c|rrrrrrr}
\hline Threshold & RSS & MSE & Fstat & Prob & Crit10 & Crit5 & Crit1 \\
\hline Single & 1.2024 & 0.0111 & 37.71 & 0.0100 & 22.7559 & 26.0080 & 33.2494 \\
Double & 0.9878 & 0.0091 & 23.46 & 0.0433 & 17.8509 & 22.6106 & 29.3152 \\
Triple & 0.8278 & 0.0077 & 20.87 & 0.4933 & 42.9419 & 50.4467 & 66.2171 \\
\hline
\end{tabular}

Source: Results calculated from Stata 16 software

The p-value of the rational rate test corresponding to the model with two public debt thresholds is 0.0433 , which is smaller than the significance level of $5 \%$. Besides, the p-value corresponding to the model with three public debt thresholds is 0.4933 , which is larger than the significance level of $10 \%$. Thus, the model of the impact of public debt on the economic growth of middle-income countries in the ASEAN+3 group has two existing values of the public debt threshold.

\subsection{Estimation Results of the Threshold regression model}

The above test results show that the model of the impact of public debt on the economic growth of all ASEAN+3 countries has two public debt thresholds. The specific estimation results are as follow:

Table 8. Estimation results of the threshold model for all ASEAN+3 countries Threshold estimator (level = 95):

\begin{tabular}{r|rrr}
\hline mode1 & Threshold & Lower & Upper \\
\hline Th-1 & 0.2696 & 0.2614 & 0.2700 \\
Th-21 & 0.2696 & 0.2614 & 0.2700 \\
Th-22 & 0.7253 & 0.6901 & 0.7403 \\
\hline
\end{tabular}




\begin{tabular}{|c|c|c|c|c|c|c|}
\hline lngdp & Coef. & Std. Err. & $\mathrm{t}$ & $P>|t|$ & [95\% Conf. & Interval] \\
\hline g & 2.763875 & .3446934 & 8.02 & 0.000 & 2.082268 & 3.445483 \\
\hline inv & -.0554992 & .2926827 & -0.19 & 0.850 & -.6342592 & .5232608 \\
\hline 1 & 2.069363 & .4355961 & 4.75 & 0.000 & 1.208001 & 2.930724 \\
\hline \multicolumn{7}{|l|}{ _cat\#c.debt } \\
\hline$\theta$ & -1.375204 & .2834305 & -4.85 & 0.000 & -1.935668 & -.8147396 \\
\hline 1 & .0891049 & .1099456 & 0.81 & 0.419 & -1283049 & .3065148 \\
\hline 2 & -.2326712 & .0746963 & -3.11 & 0.002 & - . 3803781 & - .0849644 \\
\hline _cons & 11.50093 & .2102349 & 54.71 & 0.000 & 11.08521 & 11.91666 \\
\hline sigma_u & 2.6543658 & & & & & \\
\hline sigma_e & . 10475173 & & & & & \\
\hline rho & .99844502 & \multicolumn{5}{|c|}{ (fraction of variance due to $u_{-} i$ ) } \\
\hline
\end{tabular}

Source: Results calculated from Stata 16 software.

Estimated results show that there are two thresholds of public debt, $26.96 \%$ and $72.53 \%$. Accordingly, at a public debt-to-GDP ratio below $26.96 \%$, public debt has a negative and statistically significant impact on economic growth. Specifically, when public debt increases by $1 \%$, GDP per capita will decrease by $1.38 \%$. With the public debt-to-GDP ratio from $26.96 \%$ to $72.53 \%$, the impact of public debt on GDP per capita is not statistically significant. This result shows that countries that maintain public debt-to-GDP ratio from $26.96 \%$ to $72.53 \%$ do not necessarily negatively impact economic growth. With the public debt-to-GDP rate exceeding $72.53 \%$, public debt has a negative and statistically significant impact on economic growth. Specifically, when public debt increases by 1\%, GDP per capita will decrease by $0.23 \%$.

For high-income ASEAN+3 countries, the model of public debt's impact on economic growth has one public debt threshold. The specific estimation results are as follow:

Table 9. Estimation results of the threshold model for high-income countries Threshold estimator (level = 95):

\begin{tabular}{c|ccc}
\hline model & Threshold & Lower & Upper \\
\hline Th-1 & 0.6580 & 0.0281 & 1.8066 \\
\hline
\end{tabular}




\begin{tabular}{r|rlrrrr}
\hline lngdp & Coef. & Std. Err. & $t$ & $\mathrm{P}>|\mathrm{t}|$ & [95\% Conf. Interval] \\
\hline $\mathrm{g}$ & -1.568925 & .3573009 & -4.39 & 0.000 & -2.300823 & -.8370273 \\
inv & .2901733 & .1924778 & 1.51 & 0.143 & -.1040997 & .6844462 \\
1 & 3.654448 & .4338823 & 8.42 & 0.000 & 2.76568 & 4.543215 \\
& & & & & & \\
_cat\#c.debt & & & & & & \\
0 & .2236508 & .1119304 & 2.00 & 0.055 & -.0056283 & .4529298 \\
1 & .1832989 & .0572485 & 3.20 & 0.003 & .0660307 & .300567 \\
_cons & 11.17497 & .1788449 & 62.48 & 0.000 & 10.80862 & 11.54132 \\
\hline sigma_u & 2.7547913 & & & & & \\
sigma_e & .04166171 & & & & & \\
rho & .99977134 & (fraction of variance due to u_i) & \\
\hline
\end{tabular}

$F$ test that all u_i=0: $F(2,28)=1404.36$

Prob > $F=0.0000$

Source: Results calculated from Stata 16 software.

The estimation results show the existence of a public debt threshold of $65.80 \%$. Accordingly, at a public debt-to-GDP ratio below $65.80 \%$, public debt has a positive and statistically significant economic growth impact. Specifically, when public debt increases by $1 \%$, GDP per capita will increase by $0.22 \%$. With the public debt-toGDP ratio starting from $65.80 \%$, public debt still has a positive and statistically significant impact on economic growth. However, the level of influence is weaker than the public debt-to-GDP ratio below this threshold. Specifically, when public debt increases by $1 \%$, GDP per capita will increase by $0.18 \%$.

For middle-income countries in the ASEAN+3 region, the model of public debt impact on economic growth has two public debt thresholds. The specific estimation results are as follow:

Table 10. Estimation results of the threshold model for middle-income countries Threshold estimator (level = 95):

\begin{tabular}{r|rrr}
\hline model & Threshold & Lower & Upper \\
\hline Th-1 & 0.2937 & 0.2921 & 0.2973 \\
Th-21 & 0.2696 & 0.2614 & 0.2700 \\
Th-22 & 0.7253 & 0.6901 & 0.7403 \\
\hline
\end{tabular}




\begin{tabular}{|c|c|c|c|c|c|c|}
\hline lngdp & Coef. & Std. Err. & $\mathrm{t}$ & $P>|t|$ & [95\% Conf. & Interval] \\
\hline $\mathrm{g}$ & 3.634907 & .3890813 & 9.34 & 0.000 & 2.863345 & 4.40647 \\
\hline inv & -.4034287 & .3802914 & -1.06 & 0.291 & -1.157561 & . 3507035 \\
\hline 1 & 2.204461 & .4336286 & 5.08 & 0.000 & 1.344559 & 3.064363 \\
\hline \multicolumn{7}{|l|}{ _cat\#c.debt } \\
\hline 0 & -1.294879 & .3099847 & -4.18 & 0.000 & -1.90959 & -.6801673 \\
\hline 1 & .0144978 & .1323686 & 0.11 & 0.913 & - . 2479942 & .2769897 \\
\hline 2 & -.2904367 & .1003534 & -2.89 & 0.005 & -.4894412 & -.0914322 \\
\hline _cons & 11.50528 & .2268704 & 50.71 & 0.000 & 11.05538 & 11.95517 \\
\hline sigma_u & 2.7703411 & & & & & \\
\hline sigma_e & .10121256 & & & & & \\
\hline rho & 99866702 & \multicolumn{5}{|c|}{ (fraction of variance due to $u$ i) } \\
\hline
\end{tabular}

$F$ test that all u_i=0: $F(9,104)=6577.79$

Prob > F $=0.0000$

Source: Results calculated from Stata 16 software.

Estimation results show that there are two thresholds of public debt, $26.96 \%$ and $72.53 \%$. Accordingly, at a public debt-to-GDP ratio below $26.96 \%$, public debt has a negative and statistically significant impact on economic growth. Specifically, when public debt increases by $1 \%$, GDP per capita will decrease by $1.29 \%$. With public debt-to-GDP ratio from $26.96 \%$ to $72.53 \%$, the impact of public debt on GDP per capita is not statistically significant. This result shows that countries that maintain public debt-to-GDP ratio from $26.96 \%$ to $72.53 \%$ do not necessarily negatively impact economic growth. With public debt-to-GDP rate exceeding $72.53 \%$, public debt has a negative and statistically significant impact on economic growth. Specifically, when public debt increases by $1 \%$, GDP per capita will decrease by $0.29 \%$. Thus, it can be seen that the middle-income countries in the ASEAN+3 region should maintain public debt-to-GDP ratio ranging from $26.96 \%$ to $72.53 \%$.

Thus, it can be seen that the threshold effect exists in all models of the impact of public debt on the economic growth of all ASEAN+3 countries, high-income countries in the ASEAN+3 region, and middle-income countries in the ASEAN+3 region. Specifically, with the sample being all ASEAN+3 countries, the research results indicate two thresholds of public debt to GDP. With the sample being highincome countries, the research results indicate one threshold of public debt to GDP. With the sample being middle-income countries, the research results indicate two thresholds of public debt to GDP.

Table 11. Summary of threshold model estimation results

\begin{tabular}{|c|c|c|c|c|c|}
\hline \multicolumn{2}{|c|}{ All countries } & \multicolumn{2}{c|}{ High-income countries } & \multicolumn{2}{c|}{ Middle-income countries } \\
\hline $\begin{array}{c}\text { Public debt } \\
\text { threshold }\end{array}$ & $\begin{array}{c}\text { Impact on } \\
\text { economic } \\
\text { growth }\end{array}$ & $\begin{array}{c}\text { Public debt } \\
\text { threshold }\end{array}$ & $\begin{array}{c}\text { Impact on } \\
\text { economic } \\
\text { growth }\end{array}$ & $\begin{array}{c}\text { Public debt } \\
\text { threshold }\end{array}$ & $\begin{array}{c}\text { Impact on } \\
\text { economic } \\
\text { growth }\end{array}$ \\
\hline
\end{tabular}




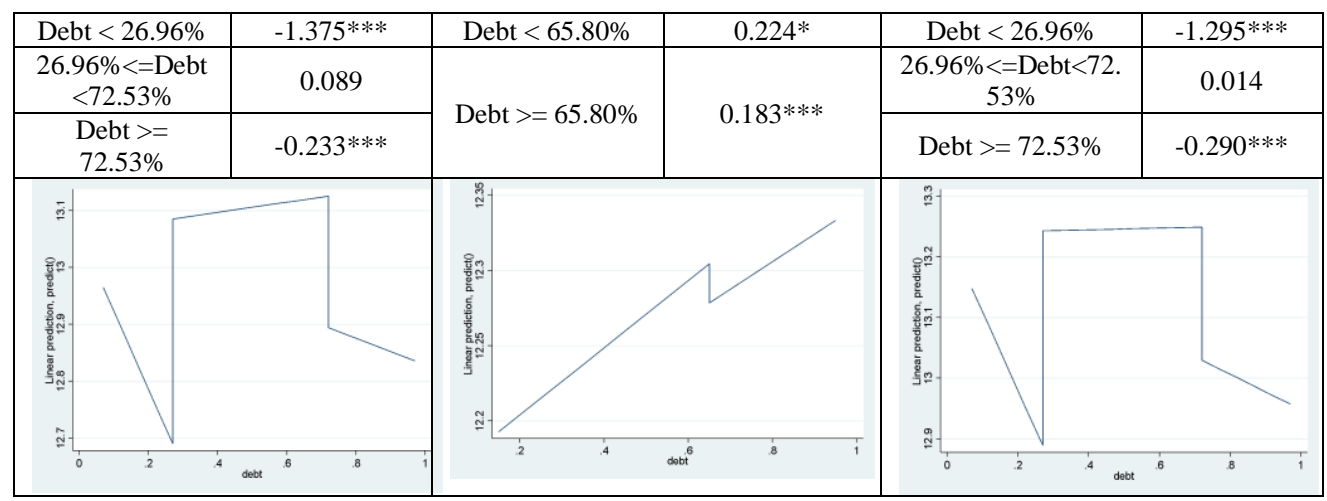

Note: *** statistically signifant at $1 \%, * *$ statistically signifant at $5 \%, *$ statistically signifant at $10 \%$.

Source: Own study.

The research results show that for middle-income countries in the ASEAN+3 region, at public debt ratio below $26.96 \%$ of GDP and $72.53 \%$ of GDP, public debt will have a negative and statistically significant impact on economic growth. This result is consistent with Timo and Florian (2015), Eberhardt, and Presbitero (2015). The measures to offset the deficit by government debt of ASEAN+3 countries do not stimulate spending in the short term because it does not increase individuals' regular income but only shifts taxes from the present to the future.

The research results also show that at public debt ratio from $26.96 \%$ of GDP to $72.53 \%$ of GDP, the impact of public debt has no statistical significance on economic growth. The positive impact that offset the negative one of public debt on economic growth may come from additional public spending financed by debt sources. To make this point clear, the authors continue to examine the impact of public spending on economic growth corresponding to public debt thresholds for all countries and middle-income countries. The estimation results are presented in the following Table 12:

Table 12. Estimation results of the impact of public spending on economic growth corresponding to public debt thresholds

All countries

Middle-income countries

\begin{tabular}{lrll}
\hline Public debt threshold & $\begin{array}{l}\text { Impact of public } \\
\text { spending } \begin{array}{r}\text { on } \\
\text { economic growth }\end{array}\end{array}$ & Public debt threshold & $\begin{array}{l}\text { Impact of } \\
\text { spending on economic } \\
\text { growth }\end{array}$ \\
\hline Debt $<26.96 \%$ & $1.774 * * *$ & Debt $<26.96 \%$ & $2.774 * * *$ \\
$26.96 \%<=$ Debt $<72.53 \%$ & $3.036 * * *$ & $26.96 \%<=$ Debt $<72.53 \%$ & $3.864 * * *$ \\
Debt $>=72.53 \%$ & $1.393 * * *$ & Debt $>=72.53 \%$ & $2.306 * * *$ \\
\hline
\end{tabular}

Note: *** statistically signicant at 1\%, ** statistically signicant at 5\%, * statistically signicant at $10 \%$.

Source: Own study. 
The research results show that public spending corresponding to all public debt thresholds has a positive and statistically significant economic growth impact. Above all, public spending corresponding to the public debt ratio ranging from $26.96 \%$ of GDP to $72.53 \%$ of GDP generates the greatest effects. This explains how public spending's positive impact increased from public debt has offset the negative impact of public debt on economic growth. As such, middle-income countries in the ASEAN+3 region are encouraged to maintain public debt ratio from $26.96 \%$ of GDP to $72.53 \%$ of GDP to ensure impact efficiency on economic growth.

\section{Conclusion}

The estimation results show that the threshold effect exists in all models of the impact of public debt on the economic growth of all ASEAN+3 countries, highincome ASEAN+3 countries, and middle-income countries in the ASEAN+3 zone. Specifically, the research results indicate two thresholds of public debt to GDP, with the sample being all ASEAN +3 countries. The research results indicate one threshold of public debt to GDP, as the sample is high-income countries. The research results indicate two thresholds of public debt to GDP, with the sample being middle-income countries.

More specifically, the research results show that public debt will have a negative and statistically significant impact on economic growth for middle-income countries in the ASEAN+3 region, a public debt ratio below $26.96 \%$ of GDP, and $72.53 \%$ of GDP. However, at a public debt ratio ranging from $26.96 \%$ of GDP to $72.53 \%$ of GDP, the impact of public debt on economic growth is not statistically significant. We prove this result that the positive impact of the increase in debt-funded government spending has offset public debt's negative impact on economic growth. Accordingly, the research results suggest that ASEAN+3 countries, most of which are middle-income countries, should maintain a public debt ratio of $26.96 \%$ of GDP to $72.53 \%$ of GDP. The public debt ratio in this limit is also suitable for high-income countries because, within this limit, public debt will have a greater impact on economic growth (in these countries, the coefficient of regression of the public debt variable below the $65.80 \%$ of GDP threshold is higher than that above). Accordingly, the study recommends strategies for handling public debt for ASEAN+3 countries, including Vietnam, from an individual perspective. The key remedy is to concentrate on reducing excessive public expenditure and reforming the tax system, enhancing investment performance, reforming the SOE, opening up state budget details, and public debt.

\section{References}

Amano, R.A., Wirjanto, T.S. 1997. Intratemporal Substitution and Government Spending. The Review of Economics and Statistics, 79(4), 605-609. 
Aschauer, D.A. 1989. Is public expenditure productive? Journal of Monetary Economics, 23(2), 177-200. https://doi.org/10.1016/0304-3932(89)90047-0.

Barro, R.J. 1989. The Ricardian to Budget Deficits. Journal of Economic Perspectives, 3(2), 37-54. https://www.jstor.org/stable/1942668.

Baum, A., Checherita-Westphal, C., Rother, P. 2013. Debt and Growth: New Evidence for the Euro Area. Journal of International Money and Finance, 32, 809-821.

Checherita-Westphal, C., Rother, P. 2012. The impact of high government debt on economic growth and its channels: An empirical investigation for the Euro area. European Economic Review, 56(7), 1392-1405.

Eberhardt, M., Presbitero, A.F. 2015. Public debt and growth: Heterogeneity and nonlinearity. Journal of International Economics, 97(1), 45-58.

Égert, B. 2015. Public debt, economic growth and nonlinear effects: Myth or reality? Journal of Macroeconomics, 43, 226-238. https://doi.org/10.1016/j.jmacro.2014.11.006.

Eisner, R. 1992. Deficits: which, how much, and so what? The American Economic Review, 82(2), 295-298. https://www.jstor.org/stable/2117417.

Elmendorf, D.W., Mankiw, N.G. 1999. Government debt. Handbook of Macroeconomics, North Holland.

George, G. 2014. Public debt, Sovereign Risk and Sustainable Development of Romania. Procedia Economics and Finance, 8, 353-361. https://doi.org/10.1016/S22125671(14)00101-4.

Gwartney, J., Lawson, R., Holcombe, R.G. 1998. The Size and Functions of Government and Economic Growth. US: Joint Economic Committee.

Hair, J.F., Anderson, R.E., Tatham, R., Black, W. 1998. Multivariate data analysis. 5th Edition, New Jersey: Prentice Hall.

Hameed, A., Ashraf, H., Chaudhary, M.A. 2008. External debt and its impact on economic and business growth in Pakistan. International Research Journal of Finance and Economics, 20, 132-140. http://www.internationalresearchjournaloffinanceandeconomics.com/ISSUES/IRJF E\%20issue\%2020.htm.

Hansen, B.E. 1999. Threshold effects in non-dynamic panels: Estimation, testing, and inference. Journal of Econometrics, 93(2), 345-368. https://doi.org/10.1016/S03044076(99)00025-1.

Keynes, J.M. 1936. The General Theory of Employment, Interest and Money. London: Palgrave Macmillan, Cham.

Kumar, M., Woo, J. 1988. Public Debt and Growth. IMF Working Paper 10/174. https://www.imf.org/en/Publications/WP/Issues/2016/12/31/Public-Debt-andGrowth-24080.

PrasadBal, D., NarayanRath, B. 2014. Pulic debt and economic growth in India: A reassessment. Economic Analysis and Policy, 44(3), 292-300. https://doi.org/10.1016/j.eap.2014.05.007.

Ricardo, D. 1951. Works and Correspondence. Edited by Piero Sraffa. 11 vols. Cambridge: Cambridge University Press.

Teles, V.K., Mussolini, C.C. 2014. Public debt and the limits of fiscal policy to increase economic growth. European Economic Review, 66(C), 1-15. https://doi.org/10.1016/j.euroecorev.2013.11.003.

Timo, M., Florian, M. 2015. Public debt and growth in German federal states: What can Europe learn? Journal of Policy Modeling, 37(2), 208-228. https://doi.org/10.1016/j.jpolmod.2015.02.003. 